\title{
Co-combustion of municipal solid waste and coal gangue in a circulating fluidized bed combustor
}

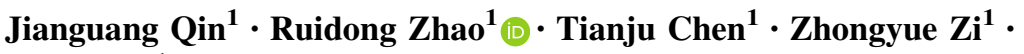 \\ Jinhu Wu ${ }^{1}$
}

Received: 8 March 2018/Revised: 28 May 2018/Accepted: 30 November 2018/Published online: 28 December 2018

(C) The Author(s) 2018

\begin{abstract}
Mixed incineration of municipal solid waste (MSW) in existing coal gangue power plant is a potentially highefficiency and low-cost MSW disposal way. In this paper, the co-combustion and pollutants emission characteristic of MSW and coal gangue was investigated in a circulating fluidized bed (CFB) combustor. The effect of MSW blend ratio, bed temperature and excess air ratio was detailedly studied. The results show the $\mathrm{NO}_{x}$ and $\mathrm{HCl}$ emission increases with the increasing MSW blend ratio and the $\mathrm{SO}_{2}$ emission decreases. With the increase of bed temperature, the $\mathrm{CO}$ emission decreases while the $\mathrm{NO}_{x}$ and $\mathrm{SO}_{2}$ emission increases. The $\mathrm{HCl}$ emission is nearly stable in the temperature range of 850-950 ${ }^{\circ} \mathrm{C}$. The increase of excess air ratio gradually increases the $\mathrm{NO}_{x}$ emission but has no significant effect on the $\mathrm{SO}_{2}$ emission. The $\mathrm{HCl}$ emission firstly increases and then decreases with the increase of excess air ratio. For a typical CFB operating condition with excess air ratio of 1.4 , bed temperature of $900{ }^{\circ} \mathrm{C}$ and $\mathrm{MSW}$ blend ratio of $10 \%$, the original CO, $\mathrm{NO}_{x}, \mathrm{SO}_{2}$ and $\mathrm{HCl}$ emissions are $52,181,3373$ and $58 \mathrm{mg} / \mathrm{N} \mathrm{m}^{3}$ respectively.
\end{abstract}

Keywords Municipal solid waste $\cdot$ Coal gangue $\cdot$ Co-combustion Circulating fluidized bed

\section{Introduction}

From 2006 to 2016, the amount of municipal solid waste (MSW) in China increases from 148 to 204 million tons (National Bureau of Statistics of China 2017). MSW disposal has become one of the most serious issues in China. Due to the advantages of volume reduction, energy recycling and hygienic control, MSW incineration has faster development than other disposal methods (Cheng and $\mathrm{Hu}$ 2010). However, the construction of MSW incineration power plant is facing great resistance because of its high investment cost and secondary pollutions, low efficiency and public protest. In comparison with establishing a new MSW incineration power station, co-combustion of MSW

Ruidong Zhao

zhaord@qibebt.ac.cn

1 Key Laboratory of Biofuel, Qingdao Institute of Bioenergy and Bioprocess Technology, Chinese Academy of Sciences, Qingdao 266101, China and coal gangue in existing power generation station has greater potential (Leckner 2007). Coal gangue is one of the largest industrial solid wastes and has low calorific value and volatile content (Liu and Liu 2010). Circulating fluidized bed (CFB) is generally used for its combustion and high-quality coal is also added to keep stable burning. MSW has high volatile content and low ignition temperature, so the co-combustion of coal gangue and MSW instead of coal can not only realize the efficient and clean disposal of MSW but also improve the combustion characteristics of coal gangue. More important, by the cocombustion of coal gangue and MSW, no new MSW incineration power station is needed which will dramatically reduce the capital investment and public resistance.

The co-combustion of coal with biomass (Akram et al. 2015; Kumar and Singh 2016; Luo and Zhou 2017) and sludge (Areeprasert et al. 2016; Kumar and Singh 2017) have been widely studied and the results verify the feasibility of co-combustion. Due to the demand of MSW disposal, the co-combustion of coal and MSW has also attracted more attention in recent years. Muthuraman et al. 
(2010a) found the ignition and carbon burnout of MSW with high ash Indian coal is even better than the Indonesian coal/Indian coal blend which indicated the feasibility for replacing Indonesian coal with MSW. Lu et al. (2016) studied the co-combustion of MSW and coal by use of numerical simulation and bubbling fluidized bed (BFB). The results show that the MSW blend ratio can be increased to $30 \%$ without major modification of the coalfired $\mathrm{BFB}$ reactor and the minimum $\mathrm{CO}$ emission was found at the mixing proportion of $20 \%$. The mixing of MSW helped to decrease the $\mathrm{SO}_{2}$ and $\mathrm{NO}$ emission. Suksankraisorn et al. (2004) investigated the co-combustion of MSW and high sulfur Thai lignite in a BFB and found the addition of MSW will lower the bed temperature and carbon combustion efficiency. The emission of $\mathrm{SO}_{2}$ can be reduced by up to $7 \%-18 \%$ as a result of fuel sulfur dilution while the NO emission slightly increases with the increase of MSW fraction. Besides of the common pollutants, it is found that the co-combustion of MSW and coal can reduce the yield and toxicity of PAHs (Polycyclic Aromatic Hydrocarbons) and PCDD/Fs (Polychlorinated dibenzo- $p$ dioxins and dibenzofurans) (Peng et al. 2016; Yan et al. 2006). The raw MSW has complicated components and various sizes which are difficult to directly combust in existing CFB. So refuse-derived Fuel (RDF) is also used instead of the raw MSW in the co-combustion and the results show the pollutants can be suppressed by the additives (such as $\mathrm{CaO}$ ) in the $\mathrm{RDF}$ preparation process (Chyang et al. 2010; Rigamonti et al. 2012; Wei et al. 2009). Besides, because of the high moisture content in MSW, hydrothermal treatment is found to be useful to improve the co-combustion of coal and MSW (Jin et al. 2013; Muthuraman et al. 2010b). Owing to the poor characteristic of coal gangue, the co-combustion of coal gangue with coal or biomass also has been studied and the results show the co-combustion can lower the ignition and burnout temperature which is beneficial to the combustion of coal gangue (Zhang et al. 2015; Zhou et al. 2015).

However, there are fewer studies on the co-combustion of coal gangue and MSW which is meaningful for the synergistic utilization of solid wastes. The great differences between the coal gangue and MSW may influence the combustion behavior of the blends. Therefore, the purpose of this study is to investigate the combustion and pollutants emission characteristic of MSW and coal gangue in a circulating fluidized bed combustor. The effect of MSW blend ratio, bed temperature and excess air ratio are described in detail.

\section{Experimental}

\subsection{Apparatus}

The experimental apparatus consists of a circulating fluidized bed combustor, a fuel feeding system, a flue gas cooler and a gravity dust filter. The schematic diagram of the experimental apparatus is shown in Fig. 1. The thermal capacity of the CFB is about $100 \mathrm{kWth}$. The combustor is composed of a furnace, a cyclone, a dipleg and loop seal. The furnace has an inside diameter of $108 \mathrm{~mm}$ and a height of $6 \mathrm{~m}$. Four electrical heaters each with the heating power of $2 \mathrm{~kW}$ are furnished along the furnace in order to raise the furnace temperature at the beginning of experiments. The inside diameter of the dipleg is $70 \mathrm{~mm}$. The fluidizing air is preheated by an air preheater and then flows into the furnace through the air distributor plate. The fuel feeding system consists of two hoppers and a screw feeder. Coal gangue and MSW are added into the hoppers after well mixed and then fed into the furnace by the screw feeder. The ash is discharged from the bottom of the furnace.

Temperature is measured by thermocouples located at heights of $150,840,2550,4170$, and $5850 \mathrm{~mm}$ above the

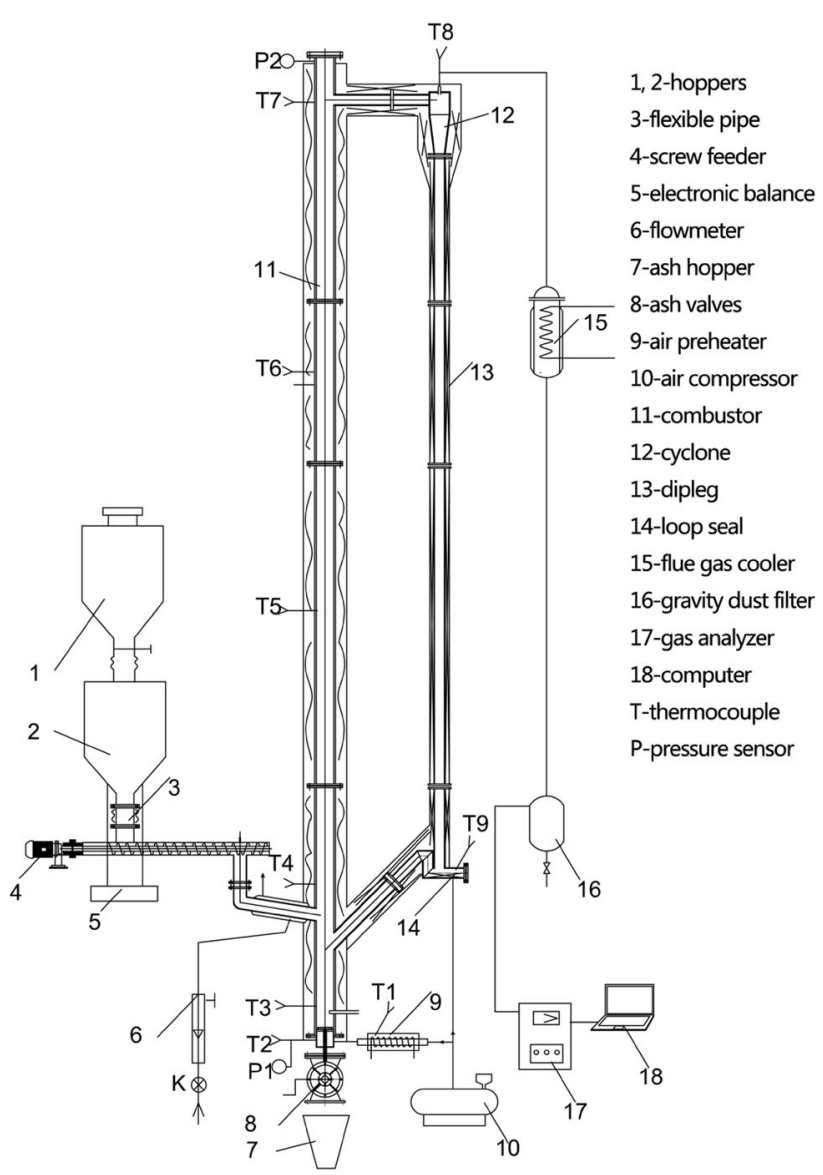

Fig. 1 Schematic diagram of the experimental apparatus 
air distributor plate and also at the air chamber, cyclone and loop seal. Pressure is measured at 100, 940, 2450, 4070 , and $5750 \mathrm{~mm}$ above the air distributor plate. The concentrations of $\mathrm{O}_{2}, \mathrm{CO}_{2}, \mathrm{CO}, \mathrm{SO}_{2}, \mathrm{NO}_{x}$ and $\mathrm{HCl}$ in the flue gas are continuously monitored online by a Madur Photon gas analyzer after the gravity dust filter.

\subsection{Fuel}

The coal gangue was provided by Pingshuo Gangue Power Generation Co., Ltd (Shuozhou City, Shanxi Province, China). It was sieved to particle sizes between 0.3 and $4 \mathrm{~mm}$. Because the composition of real MSW is complex and varied, in order to maintain the consistency of fuel properties, MSW used in present study was simulated by use of pure components (such as wood, polyethylene, rice and so on) according to the composition of real MSW in Shuozhou City (Zhao et al. 2012). These pure components are mixed evenly and then crushed into $0.5-2 \mathrm{~mm}$. The proximate and ultimate analysis of the coal gangue and MSW are shown in Table 1. In the experiments, the coal gangue and MSW were directly mixed according to the MSW blend ratio (the mass fraction of MSW in the mixed fuel) and fed into the circulating fluidized bed combustor together.

\subsection{Conditions}

The effect of bed temperature, MSW blend ratio, and excess air ratio is investigated. The base experimental conditions for these factors are $900{ }^{\circ} \mathrm{C}, 10 \mathrm{wt} \%$ and 1.3 respectively. When one of the factors is investigated, the rest remains unchanged. The variation range of bed temperature is from 780 to $950{ }^{\circ} \mathrm{C}$. The MSW blend ratio is from 0 to $30 \mathrm{wt} \%$ and the excess air ratio is from 1.2 to 1.8 . The excess air ratio is determined by $\alpha=21 /(21-\beta)$. In this equation, $\alpha$ is the excess air ratio and $\beta$ is the $\mathrm{O}_{2}$ volume concentration in the flue gas. In order to maintain the steady combustion of the mixture, the feed rate of the mixed fuel is variable according to the bed temperature. Correspondingly, the air flow rate is also changed with the feed rate to realize the specified excess air ratio. The air flow rate used in the experiments is from 40 to $65 \mathrm{~m}^{3} / \mathrm{h}$ depending on the experimental conditions.
In experiments, temperature, pressure and pollutants measurements are recorded when the system reaches steady condition (no less than $1 \mathrm{~h}$ ). The bed temperature is the arithmetic mean value of five thermocouples in the furnace. The measurement results of the gas analyzer are converted based on 6 vol\% $\mathrm{O}_{2}$ in flue gas and expressed in $\mathrm{mg} / \mathrm{N} \mathrm{m}^{3}$ (dry basis) at normal state $(273 \mathrm{~K}$ and $101 \mathrm{kPa})$.

\section{Results and discussion}

\subsection{Bed temperature}

Figure 2 shows the changes of $\mathrm{CO} / \mathrm{CO}_{2}$ emission and the ash carbon content as a function of bed temperature. Obviously, the $\mathrm{CO}$ emission and ash carbon content gradually decrease as the bed temperature rises. It means that higher bed temperature is beneficial for the complete combustion of carbon. As a result, the $\mathrm{CO}_{2}$ emission slightly increases with the increase of bed temperature.

The emission of $\mathrm{NO}_{x}$ and $\mathrm{SO}_{2}$ varying with bed temperature is shown in Fig. 3. With the increase of bed temperature, the $\mathrm{NO}_{x}$ emission increases correspondingly. When the bed temperature is $950{ }^{\circ} \mathrm{C}$, the $\mathrm{NO}_{x}$ concentration reaches $215 \mathrm{mg} / \mathrm{N} \mathrm{m}^{3}$. It is mainly because the higher temperature will strengthen the oxidization of fuel nitrogen to $\mathrm{NO}_{x}$ (Hill and Smoot 2000; Wang et al. 2012). Besides, the decrease of $\mathrm{CO}$ and char weakens the reduction reaction of generated $\mathrm{NO}_{x}$.

The $\mathrm{SO}_{2}$ concentration decreases slightly at lower temperature and then greatly increases when the bed temperature exceeds $830{ }^{\circ} \mathrm{C}$. The $\mathrm{SO}_{2}$ concentration is $3696 \mathrm{mg} /$ $\mathrm{N} \mathrm{m}^{3}$ at the bed temperature of $950{ }^{\circ} \mathrm{C}$. It is mainly because, at low temperature, the self-desulphurization efficiency by the alkali metal in the fuel is higher than the sulphur release with the increase of temperature. On the contrary, at the higher bed temperature, the sulphur retention rate will decrease because of the decomposition of sulphate while the sulphur release rate increases. As a result, the $\mathrm{SO}_{2}$ concentration firstly decreases and then begins to greatly increase (Lith et al. 2006; Knudsen et al. 2005).

The effect of bed temperature on the $\mathrm{HCl}$ emission is given in Fig. 4. The $\mathrm{HCl}$ concentration gradually increases

Table 1 Proximate and ultimate analysis of coal gangue and MSW (received basis)

\begin{tabular}{|c|c|c|c|c|c|c|c|c|c|c|}
\hline \multirow[t]{2}{*}{ Item } & \multicolumn{4}{|c|}{ Proximate analysis (\%) } & \multicolumn{6}{|c|}{ Ultimate analysis (\%) } \\
\hline & FC & V & M & A & $\mathrm{C}$ & $\mathrm{H}$ & $\mathrm{O}$ & $\mathrm{N}$ & S & $\mathrm{Cl}$ \\
\hline Coal gangue & 23.33 & 22.90 & 1.52 & 52.25 & 28.29 & 2.24 & 13.28 & 0.42 & 1.99 & 0.01 \\
\hline MSW & 8.18 & 69.64 & 8.34 & 13.80 & 39.15 & 5.93 & 30.38 & 0.93 & 0.96 & 1.01 \\
\hline
\end{tabular}




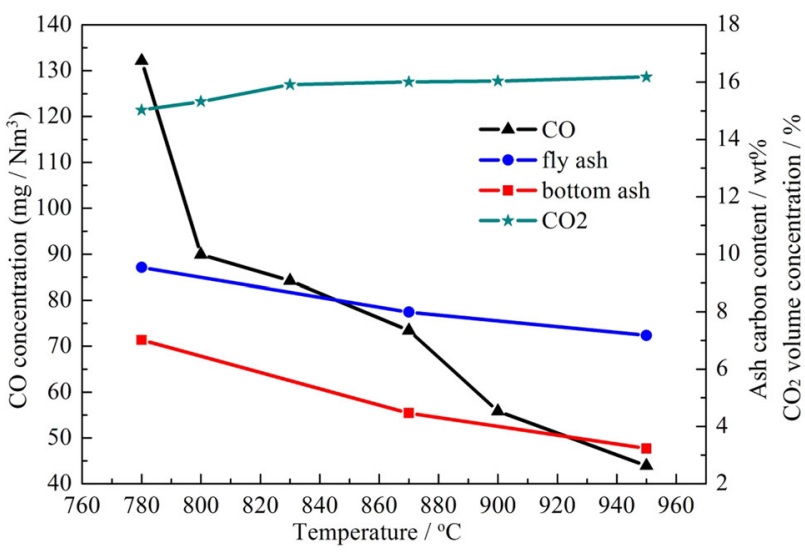

Fig. 2 Effect of bed temperature on the $\mathrm{CO} / \mathrm{CO}_{2}$ emission and carbon content in the ash

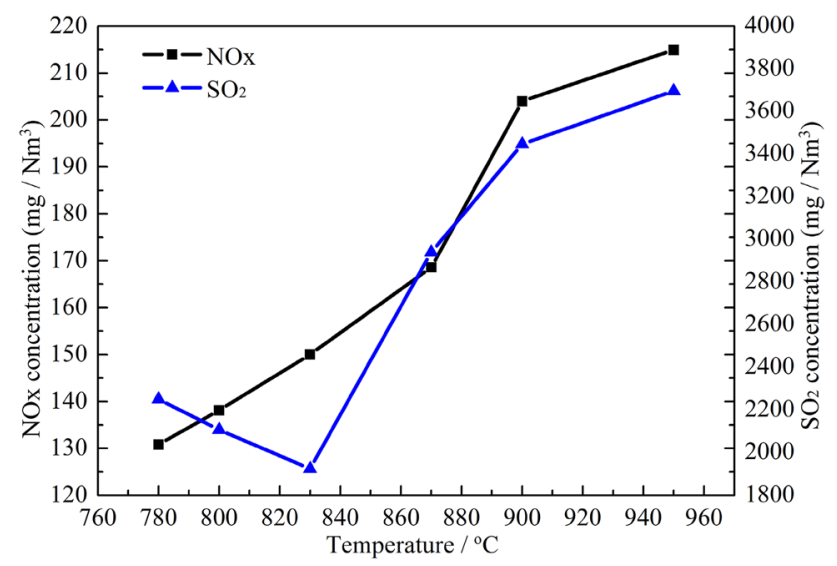

Fig. 3 Effect of bed temperature on the $\mathrm{NO}_{x}$ and $\mathrm{SO}_{2}$ emissions

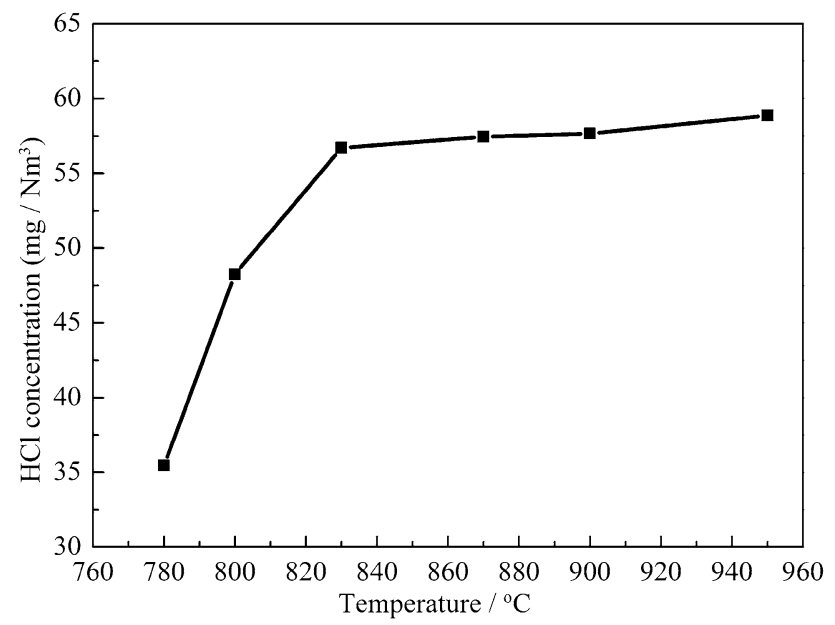

Fig. 4 Effect of bed temperature on the $\mathrm{HCl}$ emission

from 35 to $57 \mathrm{mg} / \mathrm{N} \mathrm{m}^{3}$ when the bed temperature is up to $830^{\circ} \mathrm{C}$. With further increase of temperature, the $\mathrm{HCl}$ concentration tends to be stable. In general, the operating temperature of $\mathrm{CFB}$ is about $850-950{ }^{\circ} \mathrm{C}$, which means the

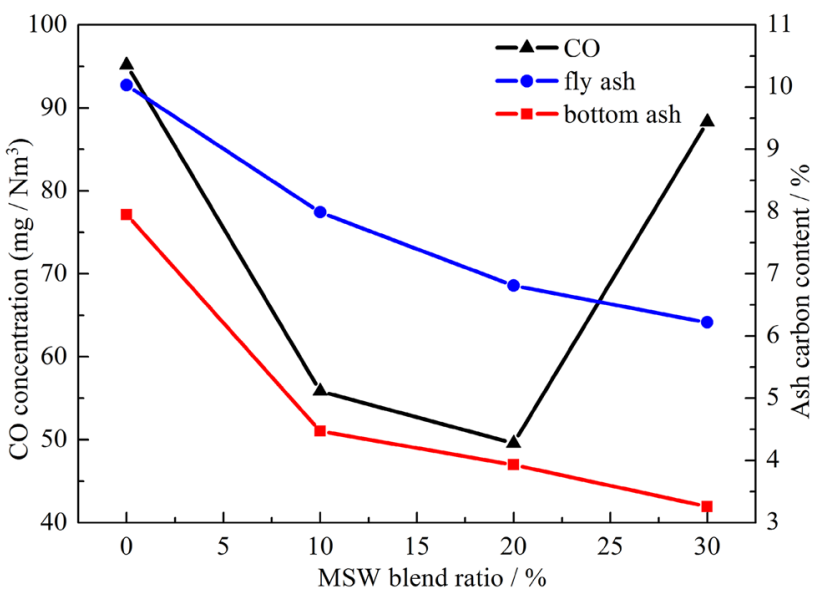

Fig. 5 Effect of MSW blend ratio on the CO emission and carbon content in the ash

$\mathrm{HCl}$ emission varies little with the bed temperature for actual CFB.

\subsection{MSW blend ratio}

Figure 5 shows the variation of $\mathrm{CO}$ emission and ash carbon content at different MSW blend ratios. With the addition of MSW, the $\mathrm{CO}$ concentration firstly decreases. The minimum CO emission is $50 \mathrm{mg} / \mathrm{N} \mathrm{m}^{3}$ when the MSW blend ratio is $20 \%$. And then the $\mathrm{CO}$ emission begins to increase. MSW has higher volatile matter content which can improve the ignition and combustion characteristic of coal gangue. So the $\mathrm{CO}$ emission will decrease at the beginning. However, with the further addition of MSW, a large number of volatile matters will be simultaneously released in the combustion and the $\mathrm{O}_{2}$ in the dilute zone of the furnace will be not sufficient. Therefore, the combustion of volatile matter is incomplete and the $\mathrm{CO}$ emission increases accordingly. The carbon content decreases with the increasing MSW blend ratio which means the addition of MSW can improve the combustion of fixed carbon.

The effect of MSW blend ratio on $\mathrm{NO}_{x}$ and $\mathrm{SO}_{2}$ is shown in Fig. 6. It can be seen that with the increase of MSW blend ratio, $\mathrm{NO}_{x}$ emission rises from 165 to $180 \mathrm{mg} /$ $\mathrm{N} \mathrm{m}^{3}$ while the emission of $\mathrm{SO}_{2}$ gradually decreases from 3585 to $3086 \mathrm{mg} / \mathrm{N} \mathrm{m}^{3}$. The $\mathrm{HCl}$ emission varying with MSW blend ratio is shown in Fig. 7. The $\mathrm{HCl}$ concentration linearly increases from 6 to $142 \mathrm{mg} / \mathrm{N} \mathrm{m}^{3}$ with the addition of MSW.

With the addition of MSW, the nitrogen, sulfur and chlorine content in the fuel are changed. So the pollutants emission depends not only on the element conversion but also on the element content. The conversion rate of different elements at different MSW blend ratio is shown in Table 2. The N, S and $\mathrm{Cl}$ conversion rate is defined as the 


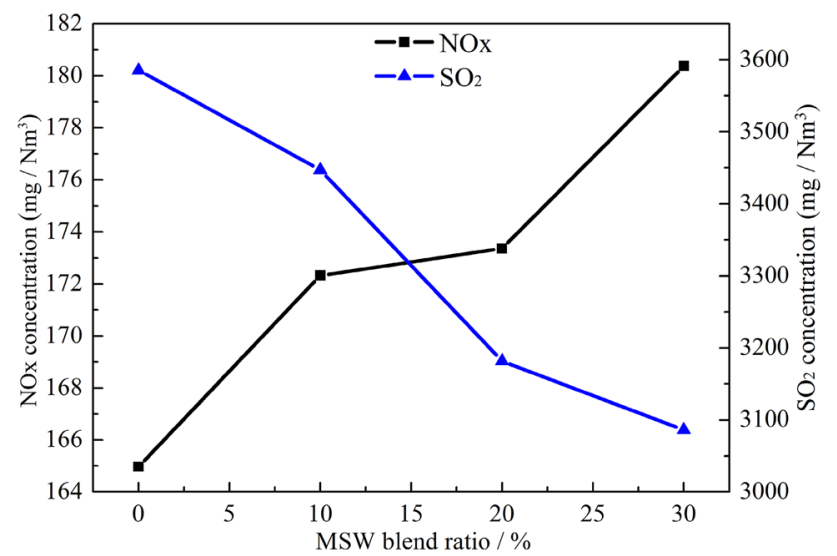

Fig. 6 Effect of MSW blend ratio on the $\mathrm{NO}_{x}$ and $\mathrm{SO}_{2}$ emissions

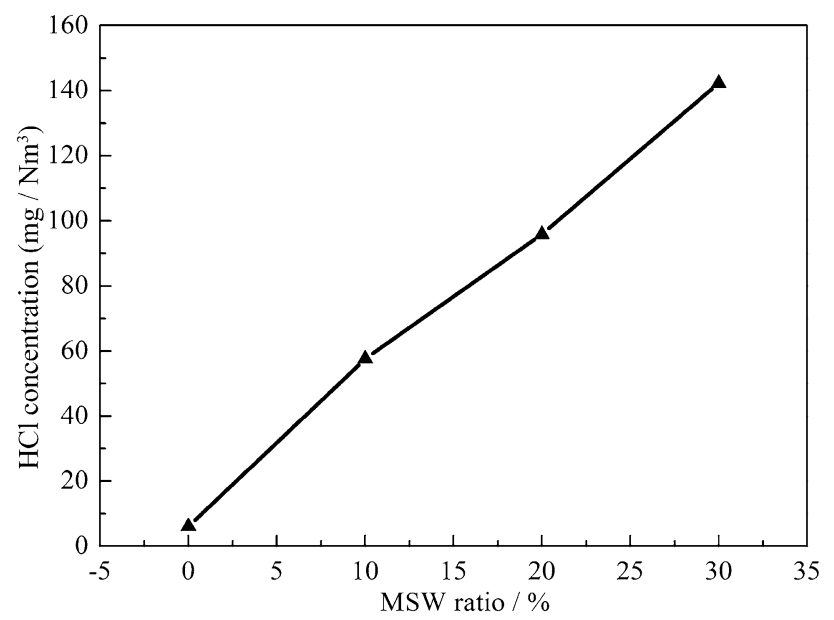

Fig. 7 Effect of MSW blend ratio on the $\mathrm{HCl}$ emission

Table 2 Conversion rate of nitrogen, sulfur and chlorine at different MSW blend ratio

\begin{tabular}{llll}
\hline $\begin{array}{l}\text { MSW } \\
\text { blend } \\
\text { ratio (\%) }\end{array}$ & N conversion (\%) & S conversion (\%) & $\mathrm{Cl}$ conversion (\%) \\
\hline 0 & 6.8 & 34.7 & 22.9 \\
10 & 6.7 & 37.2 & 21.0 \\
20 & 6.4 & 38.3 & 19.3 \\
30 & 6.4 & 41.4 & 20.4 \\
\hline
\end{tabular}

ratio between the element content in the flue gas (contained in the $\mathrm{NO}_{x}, \mathrm{SO}_{2}$ and $\mathrm{HCl}$ respectively) and the corresponding element content in the fuel. From Table 2, it can be seen with the increase of MSW blend ratio, the nitrogen conversion rate slightly decreases which is opposite to the $\mathrm{NO}_{x}$ emission. It is mainly because the nitrogen content of MSW is higher than coal gangue. More nitrogen will be released and subsequently convert to $\mathrm{NO}_{x}$ even if the conversion rate is low. Besides, the decrease of char impairs the $\mathrm{NO}_{x}$ reduction reaction. The sulphur conversion rate gradually increases with the addition of MSW. This is also opposite to the $\mathrm{SO}_{2}$ emission because the coal gangue used in present study has higher sulphur content than the MSW. The $\mathrm{HCl}$ emission obviously increases with the addition of MSW because of the extremely high chlorine content in the MSW even though the chlorine conversion rate has no obvious change. Form the changes of nitrogen, sulphur and chorine, it can be obtained that the pollutants emission is mainly determined by the corresponding elements content in the fuel. In other words, synergistic effect between coal gangue and MSW in the cocombustion is weak compared with the effect of elements content.

\subsection{Excess air ratio}

The effect of excess air ratio on the $\mathrm{CO}$ emission is shown in Fig. 8. The CO emission drops from 87 to $57 \mathrm{mg} / \mathrm{N} \mathrm{m}^{3}$ as excess air ratio increases from 1.2 to 1.4. However, further increase of excess air ratio causes $\mathrm{CO}$ emission to slightly increase. This is because the velocity in the combustor rises with the increasing excess air ratio and $\mathrm{CO}$ cannot have enough residence time to be complete combustion.

Figure 9 shows the emission of $\mathrm{NO}_{x}$ and $\mathrm{SO}_{2}$ varying with excess air ratio. The $\mathrm{NO}_{x}$ emission gradually increases from 157 to $281 \mathrm{mg} / \mathrm{N} \mathrm{m}^{3}$ with increasing excess air ratio. It is mainly because the increased $\mathrm{O}_{2}$ concentration will enhance the oxidizing conversion of fuel $\mathrm{N}$ to $\mathrm{NO}_{x}$. Besides, the decrease of $\mathrm{CO}$ can impair the reduction reaction of generated $\mathrm{NO}_{x}$.

It can be also obtained from Fig. 9 that the $\mathrm{SO}_{2}$ emission tends to be stable with the increase of excess air ratio. The whole change of $\mathrm{SO}_{2}$ emission is less than $3.5 \%$ which can be said that excess air ratio has no obvious effect on $\mathrm{SO}_{2}$ emission. Although the reducing atmosphere in the local area of the combustor may suppress the oxidization of sulphur and promote the generation of $\mathrm{H}_{2} \mathrm{~S}$, the sulphur and generated $\mathrm{H}_{2} \mathrm{~S}$ will still be oxidized to $\mathrm{SO}_{2}$ if the total $\mathrm{O}_{2}$ is enough in the combustor. Hence, the amount of $\mathrm{SO}_{2}$ emission is slightly affected.

The change of $\mathrm{HCl}$ emission with excess air ratio is shown in Fig. 10. With the increase of excess air ratio, the $\mathrm{HCl}$ emission slightly rises from 56 to $58 \mathrm{mg} / \mathrm{N} \mathrm{m}^{3}$ at the beginning and then it gradually drops to $50 \mathrm{mg} / \mathrm{N} \mathrm{m}^{3}$. The increase of excess air ratio air can promote the sufficient combustion and emission of chlorine in the fuel. But too much air will also strengthen the oxidization reaction between the generated $\mathrm{HCl}$ and $\mathrm{O}_{2}$ (shows in Eq. 1) which 


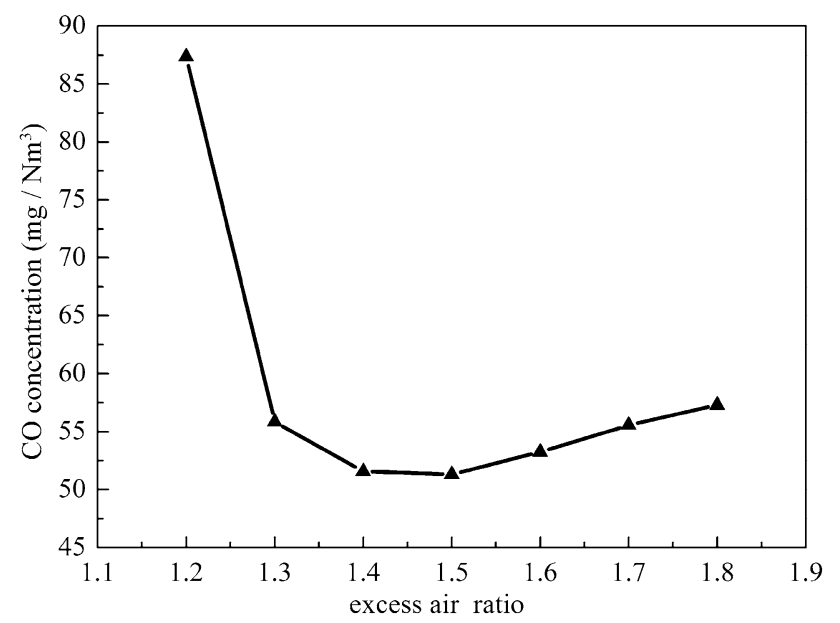

results in the consequent decease of $\mathrm{HCl}$ emission (Gullett et al. 1998).

$\mathrm{HCl}+\mathrm{O}_{2} \rightarrow \mathrm{Cl}_{2}+\mathrm{H}_{2} \mathrm{O}$.

\section{Conclusions}

Co-combustion of MSW and coal gangue in existing CFB coal gangue power station was proposed as one of the most efficient MSW disposal method. The effect of bed temperature, MSW blend ratio and excess air ratio on the cocombustion characteristic of MSW and coal gangue was investigated in a circulating fluidized bed combustor. The results can be summarized as follows:

(1) The increase of bed temperature is beneficial to complete combustion but will significantly increase the emission of $\mathrm{NO}_{x}$ and $\mathrm{SO}_{2}$. The $\mathrm{HCl}$ emission varies little with the bed temperature in the actual CFB operating temperature range $\left(850-950{ }^{\circ} \mathrm{C}\right)$.

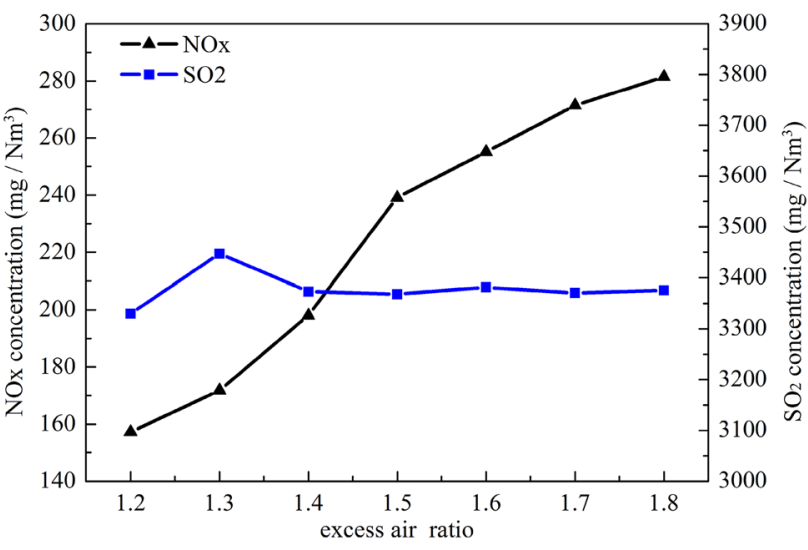

The appropriate addition of MSW can improve the combustion efficiency and the minimum CO emission of $50 \mathrm{mg} / \mathrm{N} \mathrm{m}^{3}$ is reached when the MSW blend ratio is $20 \%$. With the increase of MSW blend ratio, the $\mathrm{NO}_{x}$ and $\mathrm{HCl}$ emission increases while $\mathrm{SO}_{2}$ emission decreases due to the corresponding elements content in the mixed fuel.

(3) The optimum excess air ratio for the $\mathrm{CO}$ emission is 1.4. The increase of excess air ratio increases the $\mathrm{NO}_{x}$ emission but has no significant effect on the $\mathrm{SO}_{2}$ emission. The $\mathrm{HCl}$ emission firstly increases and then gradually decreases with the increase of excess air ratio.

Fig. 9 Effect of excess air ratio on the $\mathrm{NO}$ and $\mathrm{SO}_{2}$ emissions

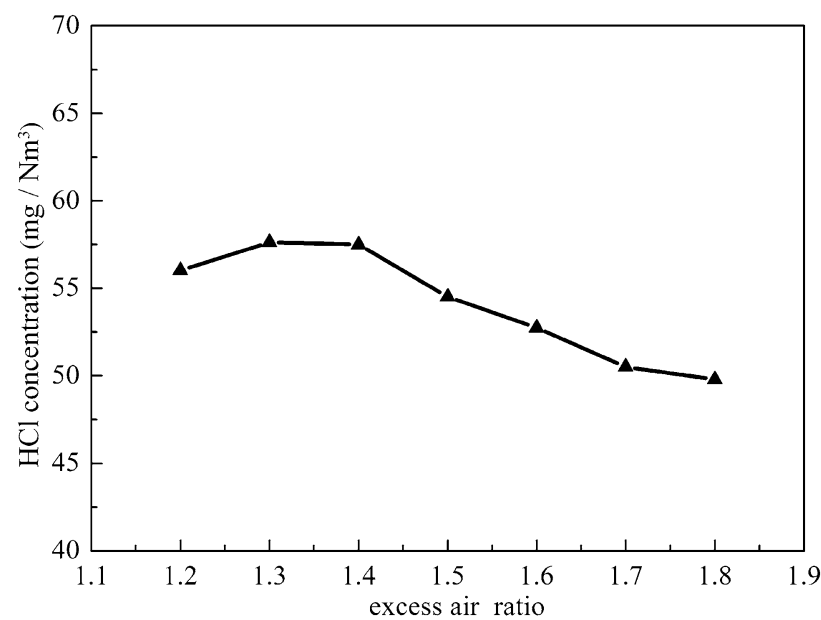

Acknowledgements This work was supported by the National Natural Science Foundation of China (Grant No. U1610254) and Shanxi Province Coal-based key Technology Research and Development Program (Grant No. MD2014-03).

Open Access This article is distributed under the terms of the Creative Commons Attribution 4.0 International License (http://crea tivecommons.org/licenses/by/4.0/), which permits unrestricted use, distribution, and reproduction in any medium, provided you give appropriate credit to the original author(s) and the source, provide a link to the Creative Commons license, and indicate if changes were made.

\section{References}

Akram M, Tan CK, Garwood DR, Fisher M, Gent DR, Kaye WG (2015) Co-firing of pressed sugar beet pulp with coal in a laboratory-scale fluidised bed combustor. Appl Energy 139:1-8

Fig. 10 Effect of excess air ratio on the $\mathrm{HCl}$ emission Chanyavanich P, Yoshikawa K (2016) Fluidized bed cocombustion of hydrothermally treated paper sludge with two coals of different rank. Fuel Process Technol 144:230-238 
Cheng HF, Hu YN (2010) Municipal solid waste (MSW) as a renewable source of energy: current and future practices in China. Bioresour Technol 101:3816-3824

Chyang CS, Han YL, Wu LW, Wan HP, Lee HT, Chang YH (2010) An investigation on pollutant emissions from co-firing of RDF and coal. Waste Manage 30:1334-1340

Gullett BK, Raghunathan K, Dunn JE (1998) The effect of cofiring high-sulfur coal with municipal waste on formation of polychlorinated dibenzodioxin and polychlorinated dibenzofuran. Environ Eng Sci 15:59-70

Hill SC, Smoot LD (2000) Modeling of nitrogen oxides formation and destruction in combustion systems. Prog Energy Combust 26:417-458

Jin YQ, Lu L, Ma XJ, Liu HM, Chi Y, Yoshikawa K (2013) Effects of blending hydrothermally treated municipal solid waste with coal on co-combustion characteristics in a lab-scale fluidized bed reactor. Appl Energy 102:563-570

Knudsen JN, Jensen PA, Lin WG, Johansen KD (2005) Secondary capture of chlorine and sulfur during thermal conversion of biomass. Energy Fuel 19:606-617

Kumar R, Singh RI (2016) An investigation in $20 \mathrm{kWth}$ oxygenenriched bubbling fluidized bed combustor using coal and biomass. Fuel Process Technol 148:256-268

Kumar R, Singh RI (2017) An investigation of co-combustion municipal sewage sludge with biomass in a $20 \mathrm{~kW}$ BFB combustor under air-fired and oxygen-enriched condition. Waste Manage 70:114-126

Leckner B (2007) Co-combustion-a summary of technology. Therm Sci 11:5-40

Lith SCV, Ramírez VA, Jensen PA, Frandsen FJ, Glarborg P (2006) Release to the gas phase of inorganic elements during wood combustion. Part 1: development and evaluation of quantification methods. Energy Fuel 20:964-978

Liu HB, Liu ZL (2010) Recycling utilization patterns of coal mining waste in China. Resour Conserv Recycl 54:1331-1340

Lu L, Ismail TM, Jin YQ, El-Salam MA, Yoshikawa K (2016) Numerical and experimental investigation on co-combustion characteristics of hydrothermally treated municipal solid waste with coal in a fluidized bed. Fuel Process Technol 154:52-65

Luo R, Zhou QL (2017) Combustion kinetic behavior of different ash contents coals co-firing with biomass and the interaction analysis. J Therm Anal Calorim 128:567-580
Muthuraman M, Namioka T, Yoshikawa K (2010a) A comparative study on co-combustion performance of municipal solid waste and Indonesian coal with high ash Indian coal: a thermogravimetric analysis. Fuel Process Technol 91:550-558

Muthuraman M, Namioka T, Yoshikaw K (2010b) A comparison of co-combustion characteristics of coal with wood and hydrothermally treated municipal solid waste. Bioresour Technol 101:2477-2482

National Bureau of Statistics of China (2017) China statistical yearbook. China Statistical Publishing House, Beijing

Peng NN, Li Y, Liu ZG, Liu TT, Gai C (2016) Emission, distribution and toxicity of polycyclic aromatic hydrocarbons (PAHs) during municipal solid waste (MSW) and coal co-combustion. Sci Total Environ 565:1201-1207

Rigamonti L, Grosso M, Biganzoli L (2012) Environmental assessment of refuse-derived fuel co-combustion in a coal-fired power plant. J Ind Ecol 16:748-760

Suksankraisorn K, Patumsawad S, Vallikul P, Fungtammasan B, Accary A (2004) Co-combustion of municipal solid waste and Thai lignite in a fluidized bed. Energy Convers Manage 45:947-962

Wang CA, Du YB, Che DF (2012) Investigation on the NO reduction with coal char and high concentration $\mathrm{CO}$ during oxy-fuel Combustion. Energy Fuel 26:7367-7377

Wei XL, Wang Y, Liu DF, Sheng HZ, Tian WD, Xiao YH (2009) Release of sulfur and chlorine during coffering RDF and coal in an internally circulating fluidized bed. Energy Fuel 23:1390-1397

Yan JH, Chen T, Li XD, Zhang J, Lu SY, Ni MJ, Cen KF (2006) Evaluation of $\mathrm{PCDD} / \mathrm{Fs}$ emission from fluidized bed incinerators co-firing MSW with coal in China. J Hazard Mater A 135:47-51

Zhang YY, Nakano J, Liu LL, Wang XD, Zhang ZT (2015) Cocombustion and emission characteristics of coal gangue and lowquality coal. J Therm Anal Calorim 120:1883-1892

Zhao Y, Xing W, Lu WJ, Zhang X, Christensen TH (2012) Environmental impact assessment of the incineration of municipal solid waste with auxiliary coal in China. Waste Manage 32:1989-1998

Zhou CC, Liu GJ, Fang T, Lam PKS (2015) Investigation on thermal and trace element characteristics during co-combustion biomass with coal gangue. Bioresour Technol 17:5454-5462 